\title{
PERAN KOMUNIKASI INTERPERSONAL ATASAN-BAWAHAN DALAM MEMOTIVASI KERJA KARYAWAN DIVISI MARKETING PT JAKARTA AKUARIUM INDONESIA
}

\author{
Anastasia Yovita Dica \\ Sekolah Tinggi Ilmu Komunikasi LSPR \\ anastasyayd@gmail.com
}

\begin{abstract}
Communication within a company plays an important role in supporting an organization to achieve its goals. Not only to achieve goals, well-established communication can also build good relationships among workers. Communication that occurs within an organization will be more effective when it happens in the form of interpersonal communication. Interpersonal communication is considered to be one of the most effective ways to convey various information about job and motivation for employees. This qualitative research using the concept of interpersonal communication as its main concept. Also, it will be associated with employee's motivation in the marketing division of PT. Jakarta Aquarium Indonesia that happens every day and is held face to face or through chat. In this study, it is also found that interpersonal communication which occurred in the marketing division of PT. Jakarta Aquarium Indonesia runs quite well. So the decrease in work motivation of subordinates not because of interpersonal communication is less effective but because of the pressure and less cooperative attitude of other division employees make the work environment becomes less comfortable.
\end{abstract}

Keywords: Interpersonal Communication; Employee Motivation; Marketing Division; Qualitative Research.

\begin{abstract}
ABSTRAK
Komunikasi dalam suatu perusahaan memegang peranan penting dalam mendukung suatu organisasi untuk mencapai tujuannya. Tak hanya untuk mencapai tujuan, komunikasi yang terjalin dengan baik juga dapat membangun hubungan yang baik antar para pekerja. Komunikasi yang terjadi dalam suatu organisasi akan lebih efektif bila terjadi dalam bentuk komunikasi interpersonal. Komunikasi interpersonal dinilai menjadi salah satu cara yang cukup efektif untuk menyampaikan berbagai informasi mengenai pekerjaan hingga motivasi kerja untuk para karyawan. Penelitian kualitatif ini menggunakan konsep komunikasi interpersonal sebagai konsep utamanya. Dan nantinya akan berhubungan dengan motivasi kerja karyawan pada divisi marketing PT. Jakarta Akuarium Indonesia yang terjadi setiap hari dan berangsung secara tatap muka ataupun melalui chating. Dalam penelitian ini pula ditemukan bahwa komunikasi interpersonal yang terjadi di divisi marketing PT. Jakarta Akuarium Indonesia berjalan dengan cukup baik. Sehingga penurunan motivasi kerja dari para bawahan bukan karena komunikasi interpersonal yang kurang efektif melainkan karena tekanan dan kurang kooperatifnya sikap dari karyawan divisi sehingga membuat lingkungan kerja menjadi kurang nyaman.
\end{abstract}

Kata Kunci: Komunikasi interpersonal; motivasi karyawan; divisi marketing; penelitian kualitatif. 


\section{PENDAHULUAN}

Komunikasi yang terjadi di suatu organisasi memegang peranan penting dalam mendukung organisasi tersebut mencapai tujuannya. Komunikasi organisasi memiliki arti penerimaan dan pengiriman pesan dalam suatu organisasi dalam kelompok formal maupun informal (Wiryanto, 2005, p. 54). Komunikasi dalam suatu organisasi ada tiga jenis, yang pertama adalah komunikasi vertical, komunikasi yang terjadi dari atasan kebawahan(downward) dan dari bawahan ke atasan (upward).

Komunikasi yang terjadi dalam suatu organisasi akan lebih efektif bila terjadi dalam bentuk komunikasi interpersonal, dimana Komunikasi interpersonal adalah komunikasi yang dilakukan oleh dua orang atau lebih dengan efek umpan balik. Kevin Hogan mengatakan bahwa komunikasi interpersonal sangatlah penting karena dengan menggunakan komunikasi tersebut, kita dapat menemukan tujuan dan kebahagiaan dialam semesta yang berupa ide-ide. (Susanto, 2014, p. 131)

Motivasi kerja karyawan dibutuhkan oleh perusahaan dalam segala bidang, Tak terkecuali pada perusahaan di bidang hospitality. Sebagai salah satu perusahaan yang bergerak dibidang hospitality, PT. Jakarta Akuarium sangat memerlukan karyawan dengan motivasi kerja yang tinggi. Bila motivasi karyawan yang berkerja di Jakarta Aquarium buruk, maka pelayanan yang diberikan juga pasti terlihat tidak maksimal. Bila pelayanan yang diberikan tidak maksimal, maka hal tersebut akan berdampak langsung pada pemasukan perusahaan. Motivasi kerja juga berkaitan erat dengan kemajuan perusahaan. Sehingga Motivasi kerja para pegawai sangat dibutuhkan agar Jakarta Aquarium dapat bertahan dalam persaingannya dengan kompetitor.

Saat ini divisi marketing di PT. Jakarta Akuarium Indonesia sedang mengalami perubahan iklim komunikasi dari manager yang lama ke manager yang baru dimana sifat dan aturan dari manager satu dengan yang lain pasti berbeda. Semenjak manager baru memegang kendali, Terlihat bahwa semangat kerja karyawan tidak seperti dulu. Tugas yang diberikan oleh atasan tidak dapat selesai sebelum waktunya. Selalu selesai pada waktu yang ditentukan atau bahkan terlambat. Waktu kedatangan para karyawan pun jarang sekali tepat waktu. Hampir setiap hari para karyawan terlambat masuk kekantor. Sehingga secara tidak langsung hal diatas mengakibatkan penurunan produktifitas.

Pernyataan ini didapatkan dari hasil wawancara pre-research pada salah satu karyawati di PT. Jakarta Akuarium Indonesia. Adapun tujuan penelitian ini adalah untuk melihat efektifitas dan peran komunikasi interpersonal antar atasan dengan bawahan di divisi Marketing PT. Jakarta Akuarium Indonesia. 


\section{TINJAUAN PUSTAKA}

De Vito mengatakan bahwa komunikasi antar pribadi adalah suatu proses pengiriman pesan dari seseorang dan diterima oleh orang lain, atau sekelompok orang dengan efek dan umpan balik yang langsung (Devito, 2011, p. 252). Komunikasi interpersonal adalah komunikasi yang terjadi antara dua orang atau lebih dan dapat terjadi baik secara langsung maupun tidak langsung. Komunikasi interpersonal membutuhkan satu orang menjadi pengirim pesan dan orang lain menjadi penerima pesan lalu akan memberikan feedback.

Komunikasi interpersonal memiliki 9 komponen, yaitu sumber/komunikator, encoding, pesan, saluran/media, penerima pesan, decoding, respon, gangguan dan konteks komunikasi (Aw, 2011, p. 5).

Devito juga mengemukakan bahwa seseorang harus memiliki 5 sikap positif ketika ia merencanakan untuk melakukan suatu komunikasi interpersonal. Jika kita dapat membangun suatu komunikasi dengan didasari dengan lima 5 sikap positif ini, maka dapat dipastikan penerima pesan akan menerima pesan kita dengan baik dan benar (Aw, 2011).

Sikap positif tersebut meliputi: (1) Keterbukaan (Openness). Keterbukaan adalah sikap dimana kita dapat menerima masukan dari orang lain dan dapat menyampaikan informasi penting ke orang lain. Sikap keterbukaan ditandai dengan adanya kejujuran dalam merspon segala stimuli komunikasi., tidak berbohong dan tidak menyembunyikan informasi. (2) Empati (Empathy). Empati adalah kemampuan seseorang untuk dapat merasakan seandainya dia menjadi orang lain. Dapat memahami dan merasakan apa yang sedang dialami orang lain,dan dapat memahami suatu persoalan dari sudut pandang orang lain. (3) Sikap Mendukung (Suportiveness). Hubungan interpersonal yang efektif adalah hubungan yang memiliki sikap saling mendukung. Artinya masing-masing pihak yang berkomunikasi memiliki komitmen untuk mendukung terselenggaranya interaksi yang terbuka. (4) Sikap Positif (Positiveness). Sikap positif ditunjukan dalam bentuk sikap dan perilaku. Dalam sikap berarti pihak yang terlibat dalam komunikasi interpersonal harus memiliki pemiliran dan perasaan yang positif, bukan berprasangka dan menyimpan curiga. Dalam perilaku berarti tindakan yang baik adalah tindakan yang relevan dengan tujuan komunikasi interpersonal, yaitu secara nyata melakukan aktivitas untuk menjalin kerjasama. (5) Kesetaraan (Equality). Kesetaraan adalah suatu pengakuan bahwa kedua belah pihak memiliki kepentingan yang sama, kedua belah pihak sama sama berharga dan bernilai. Memang bila seseorang melakukan komunikasi, tidak pernah tercapai suatu situasi yang menunjukan bahwa keduabelah orang tersebut setara. kesetaraan yang dimaksutkan disini adalah berupa pengakuan atau kesadaran serta kerelaan untuk menempatkan diri setara dengan lawan bicara. (Aw, 2011) 
Untuk Motivasi sebenarnya berasal dari kata Move yang berarti bergerak. Salah satu definisi motivasi mengatakan bahwa "motivasi adalah sesuatu yang mendorong seseorang atau kelompok untuk melakukan sesuatu ataupun tidak melakukan sesuatu". Salah satu unsur yang cukup penting dari motivasi adalah motif (alasan kita termotivasi untuk melakukan sesuatu) (Irianto, 2005, p. 53). Motivasi sendiri terbagi atas dua macam, yaitu motivasi internal dimana motivasi tersebut datangnya dari dalam diri sendiri dan motivasi eksternal dimana motivasi tersebut datang dari orang lain atau luar diri (Uno, 2011).

\section{METODE PENELITIAN}

Dalam penelitian ini, peneliti menggunakan metode penelitian kualitatif deskriptif. Data dalam penelitian ini didapatkan dari hasil wawancara terstruktur, observasi non partisipan, buku, jurnal dan internet research.

Metode penelitian yang digunakan peneliti ialah kualitatif. menurut eko sugiarto penelitian kualitatif adalah penelitian yang hasil penemuannya tidak didapatkan dari prosedur statistik atau bentuk hitung-hitungan (Sugiarto, 2015).

Teknik pengumpulan data pada penelitian ini adalah wawancara. Wawancara adalah suatu teknik pengumpulan data yang paling umum digunakan. Wawancara memiliki beberapa langkah untuk mengimplementasikannya, diantaranya memilih narasumber, membuat pertanyaan untuk narasumber, mempersiapkan wawancara, melakukan wawancara, dan yang terakhir menindak lanjuti hasil dari wawancara (Fatta, 2007, p. 69).

Untuk narasumber dari wawancara peneliti mewawancara seorang Manager marketing PT. Jakarta Akuarium Indonesia yaitu Rizqianda Saputra. Narasumber dipilih karena Manager marketing memegang kuasa tertinggi di divisi marketing dan beliau bertanggung jawab penuh atas apapun yang kerjakan karyawan dan memotivasi para karyawannya. Selain Manager, peneliti turun mewawancarai karyawan divisi marketing di PT. Jakarta Akuarium Indonesia dengan status karyawan tetap yang berjumlah 4 orang. Yaitu Luciana, Helin Faujiani Prasepti, Jonathan Setiawan dan Chintya, 24 tahun. Narasumber dipilih karena narasumber merupakan orang-orang yang merasakan perubahan iklim komunikasi di divisi marketing.

\section{HASIL DAN PEMBAHASAN}

Berdasarkan penelitian yang telah dilakukan peneliti mengenai peran komunikasi interpersonal terhadap motivasi kerja karyawan di PT. Jakarta Akuarium Indonesia, dapat dikatakan komunikasi interpersonal yang terjadi di divisi marketing PT. Jakarta 
Akuarium Indonesia cukup baik dan cukup berperan dalam memotivasi kerja karyawan. kesimpulan ini didukung oleh pernyataan dari Helin staff marketing :

"Kalo komunikasi di divisi kita sendiri sih udah lumayan kompak ya. Kita tau satu sama lain dan pekerjaan juga kebutuhan kita. Dan kita semua itu saling bantu juga. Awal awalnya sih kita masih individualis. Wajar karena kita semua kan masih generasi milenials gitu kan jadinya individual banget. Tapi makin kesini kita kaya makin gerah gitu loh. Kita kan satu divisi. Jadi dari yang tadinya kurang baik sekarang udah membaik banget" (Helin, Wawancara data primer, 20 Febuari 2018).

Devito mengatakan bahwa efektifitas suatu komunikasi interpersonal dapat dinilai melalui lima faktor yaitu keterbukaan, empati, sikap mendukung, sikap positif dan kesetaraan. Sedangkan motivasi kerja seseorang dapat muncul dari dua sumber, yaitu motivasi intrinsik dan motivasi ekstrinsik.

Keterbukaan didalam komunikasi interpersonal yang terjadi di divisi marketing PT. Jakarta Akuarium Indonesia dapat dikatakan bersifat saling terbuka antara satu dengan yang lain dan terjadi secara dua arah. Sama seperti yang dirasakan para bawahan, Rizqi selaku manager marketing juga merasakan hal yang sama.

"Karena team nya baru jadi komunikasi interpersonalnya sih sebenernya karena umurnya juga gak jauh beda masih nyambung dan terbuka sih. Cukup baik ya aku gak bilang bagus sekali karena ya namanya juga team baru, baru ketemu. dari kultur yang berbeda dari kultur perusahaan yang berbeda sebelumnya ya pasti ada bounderies nya ada plus minusnya tapi seenggaknya komunikasi memang terjadi secara dua arah sih" (Rizqianda, Wawancara data primer, 24 Januari 2018).

Topik pembicaraan antara atasan dengan bawahan tidak hanya dalam urusan pekerjaan namun urusan pribadi-pun terkadang turut menjadi topik pembahasan mereka. Kesimpulan ini sejalan dengan pernyataan jonathan:

"Emm tergantung sih. Kalo hal pribadi yg menurut saya pantas dibuka ya dibuka, kalo engga ya engga akan saya bicarakan" (Jonathan, Wawancara data primer, 20 Febuari 2018).

Hal ini sejalan dengan pernyataan Joseph A. Devito yang mengatakan bahwa kualitas keterbukaan dalam suatu komunikasi mengacu pada tiga aspek yaitu dapat saling terbuka, transparan dan dapat diterima oleh semua pihak (Devito, 2011, p. 286). Saling terbuka memungkinkan terbentuknya rasa saling mengerti dan dekat antara atasan dengan bawahan dimana rasa tersebut dapat menggerakkan para staff untuk dapat bekerja secara lebih baik lagi.

Untuk faktor empati, atasan merasa belum cukup memberikan sikap empati yang kepada seluruh bawahannya di divisi marketing PT. Jakarta Akuarium Indonesia. Namun 
sebaliknya, semua bawahan juga sudah cukup banyak menerima sikap empati dari atasannya. Mengutip dari pernyataan Rizqy, manager marketing yang mengatakan :

"Belum sih karena to be affair kan disana aku gak lama, Cuma ya yang namanya relationship yang non profesionalpun masih aku jalanin sampe sekarang. Dan sebisa mungkin yang saat itu gabisa aku kasih ya sekarang aku kasih. Soalnya waktu itu kita terbentur juga sama beberapa peraturan yang gak bisa kita langgar dan gabisa terlalu kita bisa fleksibel- in" (Rizqianda, Wawancara data primer, 24 Januari 2018).

Berbanding terbalik dengan apa yang dikatakan Rizqi, semua bawahan atau dapat kita sebut staff marketing menilai bahwa mereka sudah cukup banyak menerima sikap empati dari atasannya. Chintya dan Luciana, staff marketing memiliki pendapat yang sama bahwa:

"Sangat banyak sih, bahkan kadang kadang suka berlebihan empatinya" (Chintya, Wawancara data primer, 20 Febuari 2018).

"Kalo mas kiki orangnya lebih liberal sih menurut aku. Liberal dalam artian ya kalo misalnya dia ada kerjaan terus dia delegasiin ke kita tapi kitanya gak capable, ya dia gak akan maksa. Kan kadang ada bos yang gak mau tau pokoknya dia harus bisa gitu kan. Kalo mas kiki lebih ke nanya dulu, kalo kita gabisa ya dia gak maksa" (Luciana, Wawancara data primer, 20 Febuari 2018).

Kesimpulan diatas sesuai dengan dua hakikat empati yaitu : (1) masing-masing pihak diharapkan saling berusaha untuk merasakan apa yang dirasakan orang lain. (2) Dapat saling menghargai dan memahami pendapat, perilaku dan sikap orang lain (Devito, 2011, p. 286)

Dengan diberikan sikap empati oleh atasan, bawahan akan merasa lebih dihargai dan dimengerti. Hal tersebut menjadikan para bawahan lebih nyaman dan semangat dalam bekerja.

Faktor sikap saling mendukung yang terjadi di divisi marketing PT. Jakarta Akuarium Indonesia dapat dikatakan kurang terlaksana dengan baik karena mereka berpendapat bahwa dukungan dari atasan ke bawahan maupun sebaliknya masih sangat minim. Dikatakan sangat minim karena kesimpulan tersebut berbanding terbalik dengan pernyataan Devito yang mengatakan bahwa sikap saling mendukung dicerminkan oleh respon yang bersifat lugas dan spontan, bukan yang berkelit dan pemaparan gagasan yang bersifat deskriptif naratif, bukan evaluatif (Devito, 2011, pp. 288-289). Hal ini dapat dilihat dari kurang jelasnya pemberian arahan kerja dan motivasi kerja dari atasan ke bawahan. Kurang jelasnya pemberian arahan kerja jelas membuat para bawahan bingung dan merasa kurang didukung untuk bekerja maksimal karena bawahan kurang paham dengan apa yang diminta atasan. Pernyataan ini didukung oleh Luciana, staff marketing: 
"Hmm kalo ke aku sih mas kiki lebih sering ngasih generalnya mau apa, nanti detailnya dia serahin ke aku terserah aku maunya gimana. Ngajarin anak buahnya untuk lebih mandiri. Tapi aku emang lebih suka yg detail sebenernya" (Luciana, Wawancara data primer, 20 Febuari 2018).

Pernyataan serupa juga disampaikan oleh Chintya, staff marketing:

"Gak terlalu jelas sih sehingga dari kita sendiri harus nanya nanya dan ngulik sendiri lagi" (Chintya, Wawancara data primer, 20 Febuari 2018).

Sikap positif dapat dikatakan sangat diperlukan oleh seseorang agar dapat membentuk suatu komunikasi interpersonal yang efektif. Perhatian, dukungan dan sikap saling menghargai dari atasan adalah salah satu contoh sikap positif yang memiliki pengaruh cukup besar terhadap motivasi kerja karyawan di divisi marketing PT. Jakarta Akuarium Indonesia. Atasan sangat berusaha membangun komunikasi yang baik dan positif. Perhatian dan dukungan yang diberikan atasan memiliki pengaruh yang cukup besar terhadap motivasi kerja dari bawahan. Dapat dilihat dari pernyataan Luciana yang mengatakan:

"Ya mempengaruhi banget sih karena kalo diperhatiin dan didukung sama atasan kita pasti ngerasa "wah atasan aku perhatian nih." Jadi kita mau do the best lah gitu. Drpd atasannya cuek aja kita pasti ngerasa ah kerja gak kerja juga dia gapeduli" (Luciana, Wawancara data primer, 20 Febuari 2018).

Sama dengan para bawahannya, Rizqy memiliki pendapat yang sama :

"Sebagai manusia biasa kalo di perhatiin kita pasti akan seneng. Kalo aku sih mungkin lebih ke secondary motivation ya kaya misalnya "cyntia kerjanya yg bener nanti aku kasih ijin cuti untuk liburan". Kalo primary motivation orang kerja pasti untuk duit sih gaada yg lain. Bohong kalo dia kerja Cuma untuk mengexplorasi skill dan pengalaman. Nah sekarang tinggal gimana kita menumbuhkan secondary motivation untuk mereka" (Wawancara data primer, 24 Januari 2018).

Namun memang perhatian dan dukungan dari atasan hanya "secondary motivation" saja. Untuk motivasi utama hanya bisa diperoleh dari dalam diri sendiri.

Sikap atasan terhadap bawahan sudah sangat tepat karena sejalan dengan perilaku dan sikap dari sikap positif, antara lain (Aw, 2011, p. 83): (1) Saling menghargai (2) Berpikiran positif terhadap orang lain (3) Tidak menaruh rasa curiga secara berlebihan (4) Meyakini pentingnya orang lain (5) Memberikan pujian dan penghargaan (6) Komitmen menjalin kerjasama.

Faktor terakhir yaitu kesetaraan dimana kesetaraan yang terjalin di divisi marketing PT. Jakarta Akuarium Indonesia berjalan dengan sangat baik dimana antara atasan dengan bawahan saling bersikap terbuka, dan atasan selalu mengganggap bahwa bawahannya 
setara dengan nya, sehingga tidak terbentuk gap yang dapat mengganggu berjalannya komunikasi yang efektif. Atasan tidak memaksakan kehendak yang ia inginkan dan suasana komunikasi yang terjalin berjalan secara akrab dan nyaman. Dalam divisi marketing, atasan bersikap sangat friendly terhadap bawahannya. Atasan selalu ingin dianggap setara dengan bawahan agar tidak terbentuk gap yang terlalu jauh antara atasan dengan para bawahan. Atasan memang mengharapkan terjadi situasi yang liquid dan dinamis didalam kantor.

Hal ini disampaikan oleh rizqi, manager marketing:

"Kalo aku kan selalu bilang kalo kita disini itu as a team dan kebetulan gue udah kerja lebih duluan, gue dibayar lebih besar sedikit gitu kan, dan tanggung jawab gue lebih banyak sedikit. Ya intinya disini kita kerja bareng bareng, kita bener dan salah ya bareng bareng. Kalo buat aku ngapain ya kaya gitu? Itu justru bikin jarak lho antara kita. Jangan bikin jarak antara kita dengan team. Lebih enak kalo situasinya liquid dan dinamis" (Rizqianda, Wawancara data primer, 24 Januari 2018).

Pernyataan yang sama juga disampaikan oleh Chintya, staff marketing:

"Engga sih. Dia memposisikan diri dia as a friend dan engga ada gap antara atasan dengan bawahan sih" (Wawancara data primer, 20 Febuari 2018).

Kesimpulan ini sejalan dengan indikator kesetaraan yaitu (Aw, 2011, p. 84) : (1) Menempatkan diri setara dengan orang lain ( 2 )Menyadari akan adanya kepentingan yang berbeda (3) Mengakui pentingnya kehadiran orang lain, (4) Tidak memaksakan kehendak, (5) Komunikasi dua arah, (6) Saling memerlukan, (7) Suasana komunikasi: akrab dan nyaman.

Untuk motivasi kerja karyawan bila dilihat dari sumber timbulnya, antara atasan dan bawahan sependapat bahwa motivasi utama mereka dalam bekerja berasal dari motivasi ekstrinsik dimana Motivasi ekstrinsik memiliki definisi motivasi atau keinginan kita untuk dapat mencapai sesuatu hal dengan tujuan untuk mendapatkan penghargaan eksternal. Jadi motivasi ekstrinsik berasal dari luar diri kita (Santrock, 2003, p. 476) . hal ini didukung oleh pernyataan Luciana, Rizqianda dan Chintya yang mengatakan:

"Kalo motivasi utama aku kerja itu ya pasti karena butuh uang. kalo gabutuh kerja aku mending kebali main dipantai. Ya faktor ekstrinsik aku sih. Selain butuh uang aku juga butuh pengalaman kerja dan aktualisasi diri" (Luciana, Wawancara data primer, 20 Febuari 2018).

"Karena aku laki laki ya aku harus punya duit untuk keluargaku dan untuk aktualisasi diri. Harus punya karya dan portofolio. Anggaplah kerja ibadah, jadi kalo kerja lo bagus ya ibadah lo bagus. Buat aku sih ya as simple as that. Dulu pas aku kerja di tv aku dari yg gabisa apa apa jadi bisa semua. Ya itu lah bekerja. Dari 
yg gatau jadi tau dan yg gabisa jadi bisa" (Rizqianda, Wawancara data primer, 24 Januari 2018).

"Aku kerja karena suka sih pastinya. Karena kalo kerja tanpa passion pasti hasilnya gak akan bagus. Yang kedua pastinya untuk mencari nafkah" (Chintya, Wawancara data primer, 20 Febuari 2018).

Sedangkan penurunan motivasi kerja para bawahan di divisi marketing PT. Jakarta Akuarium Indonesia dikarenakan tekanan dan kurang kooperatifnya sikap dari karyawan divisi lain karena memang dalam beberapa hal, para karyawan didalam divisi marketing membutuhkan dukungan dan kerjasama dengan divisi lain . membuat lingkungan kerja menjadi kurang nyaman dan memang salah satu bawahan sudah merencanakan untuk resign sehingga ia sudah merasa kurang semangat dalam menjalankan pekerjaannya. Hal ini didukung oleh pernyataan Helin yang mengatakan:

"Waaaah banyak sih faktornya. Yang pasti karena lingkungan kerjanya, 80\% drama sis drpd kerjanya hahahaha Jadi males gitu, tiap hari kerja buat ngadepin drama. Tapi ga telat melulu yaaaa, karena kan suka meeting diluar juga baru ke kantor." (Helin, Wawancara data primer, 20 Febuari 2018).

Pernyataan yang sama juga disampaikan oleh Luciana:

"Iya sih aku emang kadang ngerasa agak males kekantor. males sama lingkungannya. Bukan sama atasan langsung mas kiki atau temen temen sedivisi tapi sama orang orang divisi lain yg kadang susah diajak kompromi dan kerja sama. Gitu sih tas" (Luciana, Wawancara data primer, 20 Febuari 2018).

Berbeda dengan teman-temannya, Chintya mengatakan bahwa ia memang sudah merasa tidak dapat berkembang dan akan resign sehingga motivasi bekerja otomatis menurun. Hal ini didukung oleh pernyataan Chintya:

"Sebenarnya ada beberapa hal yg mempengaruhi semangat kerjaku sih dsini. Tapi faktor utamanya karena aku udah mau resign juga sihh.. aku merasa udah achieve target ku sendiri dsini dan ga tau apa lg yg harus di kembangkan. Jadi jenuh sama pekerjaannya" (Wawancara data primer, 20 Febuari 2018).

\section{SIMPULAN}

Berdasarkan hasil penelitian yang dilakukan peneliti, dapat disimpulkan bahwa komunikasi yang terjadi di divisi marketing PT. Jakarta Akuarium Indonesia adalah mayoritas berbentuk komunikasi interpersonal. Baik atasan maupun bawahan menyatakan bahwa motivasi pertama mereka untuk bekerja mereka berasal dari motivasi ekstrinsik dimana sebagai manusia biasa, mereka membutuhkan uang untuk dapat hidup lebih layak dan untuk pengaktualisasian diri mereka. Dari penelitian ini pula, 
dapat disimpulkan bahwa Komunikasi interpersonal yang terjadi antara atasan dan bawahan di PT. Jakarta Akuarium Indonesia dapat dikatakan cukup baik walau memang ada beberapa hambatan. Pernyataan ini didukung oleh hasil kesimpulan dari wawancara peneliti terhadap para narasumber mengenai 5 faktor efektifitas komunikasi interpersonal, yaitu: Keterbukaan komunikasi yang terjadi di divisi marketing PT. Jakarta Akuarium Indonesia dapat dikatakan baik karena antara atasan dan bawahan saling bersikap terbuka dan responsif sehingga mereka merasa nyaman dalam berkomunikasi antara satu dengan yang lain. Sikap empati yang diberikan atasan ke bawahan sangat banyak dan begitu juga sebaliknya. Atasan juga sangat mengerti terhadap masalah dan keluhan yang dihadapi bawahan. Untuk sikap saling mendukung, bawahan merasa bahwa atasan kurang mendukung para bawahan untuk bekerja secara maksimal dikarenakan sering kali atasan memberikan arahan kerja yang kurang jelas sehingga bawahan harus menerka-nerka sendiri apa yang diinginkan atasan dan bawahan juga merasa kurang diberikan motivasi untuk bekerja. Komunikasi interpersonal yang terjadi dalam divisi marketing PT. Jakarta Akuarium Indonesia juga penuh dengan sikap positif dimana dalam komunikasi yg terjadi, minim ditemukan salah persepsi maupun asumsi negatif. Bilamana terjadi, antara atasan dan bawahan dapat mengatasi hal tersebut dengan baik. Kesetaraan yang dibentuk oleh atasan dapat dikatakan sangat berhasil karena bawahan merasa bahwa atasan sangat friendly dan selalu ingin dianggap setara dengan para bawahannya.

Dilihat dari kesimpulan terhadap 5 faktor efektifitas komunikasi interpersonal diatas, peneliti menemukan bahwa komunikasi interpersonal yang terjalin antara atasan dengan bawahan berjalan secara cukup baik dan memiliki peran dalam memotivasi kerja karyawan di divisi marketing PT. Jakarta Akuarium Indonesia. Sehingga peneliti dapat menyimpulkan bahwa penurunan motivasi kerja para bawahan di divisi marketing PT. Jakarta Akuarium Indonesia bukan karena kurang efektifnya komunikasi interpersonal yang terjadi didalamnya, melainkan karena tekanan dan kurang kooperatifnya sikap dari karyawan divisi lain yang membuat lingkungan kerja menjadi kurang nyaman dan memang salah satu bawahan sudah merencanakan untuk resign sehingga ia sudah merasa kurang semangat dalam menjalankan pekerjaannya. Saran praktis yang dapat peneliti sampaikan untuk atasan pada divisi marketing PT. Jakarta Akuarium Indonesia agar dalam berkomunikasi dapat bersikap lebih tegas dan dapat memberikan arahan pekerjaan lebih detail dan jelas agar para bawahan dapat langsung mengerjakan pekerjaan yang diberikan tanpa harus bertanya- tanya kembali. dan saran praktis untuk bawahan adalah alangkah lebih baik bila para bawahan dapat menurunkan keegoisan masing masing dan dapat lebih semangat dalam bekerja demi kemajuan perusahaan 


\section{DAFTAR PUSTAKA}

Aw, S. (2/011). Komunikasi Interpersonal. Yogyakarta: Graha Ilmu.

Devito, J. A. (2011). KOMUNIKASI ANTARMANUSIA. Pamulang: KARISMA Publishing Group.

Fatta, H. A. (2007). Analisis dan Perancangan Sistem Informasi untuk Keunggulan Bersaing Perusahaan dan Organisasi Modern. Yogyakarta: CV Andi Offset.

Herri Susanto, S. M. (2014). Communication Skills "Sukses Komunikasi, Presentasi dan Berkarier!". Sleman: deepublish.

Irianto, A. (2005). BORN TO WIN Kunci Sukses yang Tak Pernah Gagal. J/akarta: PT Gramedia Pustaka Utama.

Santrock, J. (2003). Adolescence. Jakarta: Erlangga.

Sugiarto, E. (2015). menyusun proposal penelitian kualitatif : skripsi dan tesis. Yogyakarta: Suaka Media.

Susanto, H. (2014). Communication Skills "Sukses Komunikasi, Presentasi dan Berkarier!". Sleman: deepublish

Uno, H. B. (2011). Teori Motivasi dan Pengukurannya analisis di bidang pendidikan. Jakarta: PT Buni Aksara.

Wiryanto. (2005). Pengantar Ilmu Komunikasi. Jakarta: Gramedia Widiasarana Indonesia. 